\title{
ANALISIS KEMAMPUAN PEMAHAMAN MATEMATIS MELALUI MODEL PEMBELAJARAN STUDENT ACHIEVEMEN DIVISONS (STAD)
}

\author{
Vevi Hermawan ${ }^{1}$, Agus Dede Anggiana ${ }^{2}$, Syifa Septianti ${ }^{3}$ \\ ${ }^{1}$ Universitas Pasundan, ${ }^{2}$ Universitas Pasundan, ${ }^{3}$ Universitas Pasundan \\ vevi_pmat@unpas.ac.id
}

\begin{abstract}
ABSTRAK
Penelitian ini bertujuan untuk : (1) Menganalisis konsep kemampuan pemahaman matematis, (2) Menganalisis konsep model pembelajaran Student Teams Achievement Divisions (STAD), (3) Menganalisis kemampuan pemahaman matematis melalui model pembelajaran Student Teams Achievement Divisons (STAD). Metode yang digunakan dalam penelitian ini adalah metode penelitian kualitatif dengan jenis penelitian kepustaan atau library research. Sumber data yang digunakan adalah data primer dan data sekunder. Teknik yang digunakan pada penelitian ini yaitu Editing, Organizing dan Finding. Analisi data yang digunakan pada penelitian ini adalah Deduktif, Induktif, dan Histori. Hasil penelitian ini menunjukkan bahwa : (1) Kemampuan pemahaman matematis merupakan kemampuan individu untuk memahami, menjelaskan, serta mengungkapkannya kembali suatu materi pelajaran, dalam pelajaran matematika individu dapat menggunakan konsep, dapat menserjemahkan ke dalam bentuk lain misalnya dari kata-kata menjadi simbol, tabel, grafik, atau bentuk lainnya serta dapat menginterpretasikan ke bentuk penjelasan ringkasan, dan mengaplikasikannya pada kasus yang sederhana atau khusus, (2) Model pembelajaran Student Teams Achievement Divisions (STAD) menuntut peserta didik secara aktif yang terdiri dari lima langkah, yaitu: penyajian materi, pembagian kelompok,tes individual,perhitungan skor individu, dan rekognisi kelompok, (3) Kemampuan pemahaman matematis di tingkatan Sekolah Menengah Pertama (SMP) dan Sekolah Menengah Atas (SMA) mengalami peningkatan setelah menggunakan model pembelajaran Student Teams Achievement Divison (STAD).
\end{abstract}

Kata Kunci : Kemampuan Pemahaman Matematis, Model Pembelajaran Student Teams Achievement Divison (STAD).

\begin{abstract}
This study aims to: (1) analyze the concept of mathematical understanding ability, (2) analyze the concept of the Student Teams Achievement Divisions (STAD) learning model, (3) analyze the mathematical understanding ability through the Student Teams Achievement Divisions (STAD) learning model. The method used in this research is a qualitative research method with the type of library research. Sources of data used are primary data and secondary data. The techniques used in this research are Editing, Organizing and Finding. The data analysis used in this research is deductive, inductive, and historical. The results of this study indicate that: (1) Mathematical understanding ability is an individual's ability to understand, explain, and re-express a subject matter, in mathematics lessons individuals can use concepts, can translate into other forms, for example from words to symbols, tables. , graphs, or other forms and can be interpreted in the form of a summary explanation, and apply it to simple or special cases, (2) The Student Teams Achievement Divisions (STAD) learning model requires students to be active which consists of five steps, namely: presentation of material, group division, individual tests, individual score calculations, and group recognition, (3) The ability to understand mathematics at the junior high school (SMP) and high
\end{abstract}


school (SMA) levels has increased after using the Student Teams Achievement Division (STAD) learning model.

Keywords: Mathematical Understanding Ability, Student Teams Achievement Division (STAD) Learning Model.

\section{PENDAHULUAN}

Kemampuan pemahaman matematis adalah kompetensi dasar dalam belajar matematika yang meliputi kemampuan peserta didik dalam menyerap suatu materi, mengingat rumus dan konsep matematika, serta menerapkannya dalam kasus sederhana atau serupa, memperkirakan kebenaran suatu pernyataan, dan menerapkan rumus dan teorema dalam penyelesaian masalah (Hendriana et al,. 2017, hlm. 6). Oleh karena itu, betapa pentingnya kemampuan pemahaman matematis dapat dimiliki oleh peserta didik. Skemp (Hendriana, Rohaeti, dan Sumarmo, 2017, hlm.4) mengungkapkan terdapat dua jenis pemahaman matematis, yaitu a. pemahaman instrumental, adalah pemahaman yang hafal akan sesuatu secara terpisah dan menerapkan dalam sesuatu perhitngan rutin atau sederhana, mengerjakannya secara algoritma; dan b. pemahaman relasional, adalah pemahaman yang dikatakan melakukan perhitungan secara bermakna pada permasalahan yang lebih luas, yang termasuk skema atau struktur yang dapat digunakan penyelesaian yang lebih luas, dapat mengaitkan suatu konsep atau prinsip lainnya dan kebermaknaan dalam sifatnya.

Polattsek (Hendriana, Rohaeti, dan Sumarmo, 2017, hlm.4) membedakan dua jenis pemahaman, yaitu a. pemahaman komputasional yaitu pemahaman yang dapat menerapkan konsep dan rumus dalam perhitungan rutin atau sederhana, dan mengerjakan secara algoritma, b. pemahaman fungsional yaitu mengkaitkan suatu konsep ke konsep lainnya secara benar dan menyadari proses yang dilakukannya. Copeland juga mengungkapkan dua jenis pemahaman matematis, yaitu : a. knowing how to, dapat mengerjakan sesuatu secara rutin dan algoritmatik, b. knowing, mengerjakan kegiatan matematis secara sadar akan suatu proses yang kerjakan.

Ruseffendi (Hendriana, Rohaeti, dan Sumarmo, 2017, hlm.4) mengungkapkan tiga jenis pemahaman, yaitu a. Pengubahan (translation) merupakan merubah suatu pemahaman dalam bentuk grafik, tabel, dsb, merubah soal betuk kalimat menjadi bentuk simbol atau sebaliknya; b. Interpretasi (interpretation) merupakan penggunaan konsep yang benar dalam penyelesaian soal, juga dapat mengartikan suatu kesamaan; c. ektrapolasi (extrapolation), merupakan menerapkan berbagai konsep dalam perhitungan matematis, juga dapat memperkirakan suatu diagram. Pemahaman adalah suatu proses dan cara menerjemahkan suatu keadaan serta fakta yang dapat diketahuinya berlandaskan pada 
tingkat kemampuan yang dimiliki setiap individu. Pemahaman bukan sekedar mengetahui serta mengungkapkan ulang apa yang dipelajari. Akan tetapi, pemahaman dapat mengetahui makna yang terkandung dalam inforrmasi tersebut.

Terdapat beberapa arti dari kata pemahaman, Sumarmo (Firmansyah, 2016, hlm. 41) mengungkapkan arti kata dari understanding. Ruseffendi (Firmansyah, 2016, hlm. 41) mengungkapkan arti kata dari comprehension. Sedangkan menurut Anshar (Firmansyah, 2016, hlm. 41) mengungkapkan pemahaman sebagai terjemahan dari knowledge. Pemahaman merupakan cara memahami dan mengerti benar sesuatu. Bila peserta didik memahami sesuatu, ini berarti bahwa peserta didik mengerti benar tentang sesuatu (Russefendi, dalam Firmansyah, 2016, hlm. 41). Sejalan dengan itu, Dimyati dan Mudjiono (Firmansyah, 2016, hlm. 41) mengungkapkan bahwa pemahaman adalah kemampuan dalam menerjemahkan, menafsirkan, memperkirakan, memahami isi pokok materi dan mengartikan sebuah tabel. Beralih dari kata pemahaman, maka kita akan membahas mengenai kemampuan pemahaman matematis. Lestari \& Yudhanegara (Ridha \& Afriansyah, 2019, hlm. 516) kemampuan pemahaman matematis ialah kemampuan individu dalam penyerapan dan memahami ide-ide matematika. Septriani (Njatlama et al,. 2020, hlm. 14) kemampuan pemahaman matematis adalah kemampuan peserta didik yang dapat memahami suatu materi pelajaran, dalam pelajaran matematika, dengan hasil dari pembentukan pemikirannya sendiri serta dapat menyatakan kembali dalam bentuk yang lain yang mudah dimengerti dan dapat mengaplikasikan. Kemudian, Duffin \& Simpson (Njatlama et al,.2020, hlm. 14) kemampuan pemahaman matematis adalah kemampan peserta didik untuk : a) menjelaskan konsep, yang dapat diartikan peserta didik mampu mengungkapkan kembali apa yang telah dikomunikasikan; b) menggunakan konsep pada berbagai situasi yang berbeda; c) mengembangkan beberapa akibat dari adanya suatu konsep, yang dapat diartikan bahwa peserta didik paham terdapat suatu konsep akibatnya peserta didik mampu mempunyai kemampuan untuk dapat menyelesaikan masalah dengan benar.

Namun, kenyataan yang terjadi saat ini menunjukkan masih rendahnya kemampuan pemahaman matematis. Hal ini sejalan dengan penelitian yang dilakukan oleh Yustianingrum et al,. (2019, hlm. 44) bahwa pada hasil observasi yang dilakukan peneliti di SMAN 15 Tekagon menunjukan bahwa masih banyak peserta didik yang belum mampu memahami soal sisem persamaan linear tiga variabel (SPLTV) yang telah disajikan. Sehingga, peserta didik belum mampu dalam memahami, menggunakan, memanfaatkan, 
serta memilih prosedur atau operasi tertentu dari konsep secara algoritma dan mengaplikasikannya dalam pemecahan masalah, serta peserta didik juga belum mampu dalam menentukan himpunan penyelesaiannya dengan benar. Kemudian, hal ini dibenarkan oleh pendapat Ningsih (Nurochmah et al,. 2016, hlm.17) yang menyatakan bahwa masalah utama yang sering dihadapi pada pelajaran matematika adalah rendahnya kemampuan pemahaman matematis peserta didik, dari permasalahan tersebut yaitu pendekatan pembelajaran yang dipakai selama ini masih menggunakan pendekatan tradisional yang menekankan pada latihan mengerjakan soal serta menggunakan rumus.

Indikator kemampuan pemahaman matematis menurut NCTM (Hendriana, dkk, 2017, hlm. 7) , sebagai berikut: a) mendeskripsikan konsep secara verbal dan tulisan, b) mengidentifikasi dan membangun contoh dan bukan contoh, c) mempergunakan model, diagram, dan simbol-simbol untuk mempresentasikan suatu konsep, d) mengganti suatu bentuk representasi ke bentuk representasi lainnya, e) mengenal berbagai makna, dan interpretasi konsep, f) mengidentifikasi sifat suatu konsep dan mengetahui syarat yang menentukan suatu konsep, g) membandingkan dan membedakan konsep-konsep.

Indikator kemampuan pemahaman matematis menurut Skemp yang didasari pada indikator pemahaman menurut Klickpat \& Findell (dalam Ridia \& Afriansyah , 2019, hlm. 516) yaitu : 1) menjelaskan ulang sebuah konsep, 2) mengklasifikasikan berbagai objek berdasarkan dipenuhi atau tidaknya persyaratan yang membentuk konsep tersebut, 3) mengimplementasaikan konsep secara algoritma, dan 4) menyajikan contoh yang dipelajari.

Indikator pemahaman matematis melalui menurut Dirjen Dikdasmen Nomor 506/C/Kep/PP/2004 (dalam Njatklama et al,. 2020, hlm. 14) merinci indikator pemahaman konsep matematis adalah siswa mampu: a. Menyatakan ulang sebuah konsep. b. Mengklasifikasikan objek menurut tertentu sesuai dengan sifatnya. c. Memberikan contoh dan bukan contoh dari suatu konsep. d. Menyajikan konsep dalam berbagai bentuk representasi matematis. e. Mengembangkan syarat perlu atau syarat cukup dari suatu konsep. f. Menggunakan dan memanfaatkan serta memilih prosedur atau operasi tertentu. g. Mengaplikasikan konsep atau algoritma dalam pemecahan masalah. Sedangkan, Sumarmo (dalam Firmansyah, 2016) mengungkapkan beberapa indikator pemahaman matematis, yang meliputi : mengenal, memahami, dan menerapkan konsep, prosedur, prinsip, dan ide matematika.

Menurut Rahayu et al,. (2020, hlm. 53) Indikator yang digunakan untuk mengukur kemampuan pemahaman matematis adalah sebagai berikut:1) menjelaskan ulang sebuah 
konsep, 2) mengelompokkan beberapa objek menurut sifat-sifat tertentu sesuai dengan konsepnya, 3) menyajikan contoh dan bukan contoh dari konsep, 4) menampilkan suatu konsep dalam berbagai bentuk representasi matematis, 5) mengembangkan syarat perlu atau syarat cukup suatu konsep, 6) memakai dan manfaatkan serta memilih prosedur atau operasi tertentu, dan 7) menerapkan konsep atau algoritma pemecahan masalah.

Dalam meningkatkan kemampuan pemahaman matematis peserta didik salah satunya adalah dengan menggunakan model pembelajaran yang inovatif. Model pembelajaran inovatif adalah pembelajaran yang berpusat pada peserta didik. Model pembelajaran dikatakan berpusat pada peserta didik jika menuntut partisipasi aktif dari peserta didik itu sendiri, seperti pembelajaran yang dilakukan dengan berbagi pengalaman dalam diskusi kelompok dan bekerjasama (Rahayu et al,. 2020, hlm. 52). Menurut Adnyasari, Suadnyana dan Wiarta (Rahayu et al,. 2020, hlm. 52) salah satu model pembelajaran inovatif adalah model pembelajaran kooperatif. Model pembelajaran kooperatif dapat meningkatkan kemampuan pemahaman matematis peserta didik karena dalam kegiatan pembelajaran dibentuk kelompok yang berisi beragam kemampuan peserta didik, selain itu model pembelajaran kooperatif juga model yang sederhana dan mudah diterapkan oleh guru yang baru menggunakannya. Model pembelajaran kooperatif yang dimaksudkan tersebut adalah Student Team Achievement Divisions (STAD). Model pembelajaran kooperatif memiliki macam-macam tipe, salah satunya tipe STAD (Student Teams Achievement Division). Slavin (Yustianingsih et al,. 2019, hlm. 45) juga mengungkapkan bahwa model pembelajaran STAD (student teams achievement division) ialah salah satu pembelajaran kooperatif yang sangat sederhana serta mudah digunakan bagi guru pemula, dalam penerapan pembelajaran kooperatif yang terdiri dari lima komponen yaitu presentasi kelas, pembentukan tim, kuis, skor kemajuan individual, dan rekognisi tim.Sejalan dengan itu, menurut Riyanto (Siregar, 2019, hlm. 18) bahwa pembelajaran kooperatif tipe STAD adalah pembelajaran yang teriri atas persentasi kelas, pembentukan tim, kuis, perubahan/perkembangan skor dan pengakuan tim.

Sejalan dengan itu, Saragih (2013, hlm. 179) model pembelajaran kooperatif tipe STAD (student teams achievement division) adalah salah satu model pembelajaran kooperatif yang cukup mudah dan pendekatan yang paling baik utuk digunakan guru yang baru dalam menerapkan pembelajaran kooperatif. Sedangkan, Arifin et al,.(2019, hlm. 60) model pembelajaran Student Teams Achievement Divisions (STAD) merupakan salah satu model pembelajaran kooperatif dimana pada model pembelajaran ini ditekankan pada 
prestasi kelompok yang didapatkan dari hasil penjumlah seluruh skor kemajuan individu setiap anggota kelompok. Menurut Huda (Afriansyah \& Ridia, 2019, hlm. 517) model pembelajaran Student Teams Achievement Division) merupakan salah satu strategi pembelajaran kooperatif yang didalamnya beberapa kelompok kecil peserta didik dengan tingkatan kemampuan akademik yang beragam, saling bekerja sama untuk mencapai tujuan pembelajaran. Sejalan dengan itu, Marbun (2019, hlm. 50) pembelajaran kooperatif tipe Student Teams Achievement Division (STAD) yaitu suatu sistem pembelajaran yang memberikan kesempatan kepada peserta didik untuk belajar satu sama lain untuk memastikan bahwa tiap anggota dalam kelompok telah menguasai berbagai konsep yang telah dibahas. Dalam model pembelajaran kooperatif tipe STAD (Student Teams Achievement Division), terdapat gagasan utama. Gagasan utama STAD (Anam et al., 2016, hlm. 16) adalah mempercepat peserta didik untuk saling mendorong serta mendukung satu sama lain untuk menyelesaikan masalah yang diberikan oleh guru. Apabila peserta didik mengincar kelompoknya mendapatkan sebuah hadiah maka peserta didik perlu membantu satu sama lain didalam kelompoknya untuk mempelajari pelajaran. Sejalan dengan itu, Gagasan utama STAD menurut Njatlama et al,. (2020, hlm. 15) adalah mempercepat peserta didik agar saling mendukung antara satu sama lain untuk menguasai keterampilan yang diberikan oleh guru. Sama hal nya, jika ingin mendapatkan hadiah maka peserta didik perlu membantu teman sekelompoknya untuk belajar. Semiawan (dalam Nurhayati dan Hartono, 2017, hlm. 4) bahwa para psikolog pada umumnya sepakat bahwa peserta didik akan mudah memahami konsep yang kompleks serta abstrak apabila disertai dengan contoh yang konkrit dan bekerja sama. Model pembelajaran kooperatif tipe STAD dengan pendekatan RME merupakan salah satu model dan pendekatan yang sesuai dengan pendapat Semiawan. STAD merupakan model pembelajaran kooperatif dimana peserta didik belajar bersama dalam kelompok yang heterogen dan metode pembelajaran dengan pendekatan RME yang diawali dengan masalah dunia nyata, sehingga pembelajaran kolaborasi STAD dengan pendekatan RME memungkinkan peserta didik untuk memahami konsep yang rumit dan abstrak. Dari pemaparan diatas, didapatkan bahwa kemampuan pemahaman matmatis meningkat dipengaruhi model pembelajaran kooperatif tipe STAD.

Tahapan dalam pelaksanaan model pembelajaran Student Teams Achievement Division (STAD) menurut Kurniasih \& Sani (2015, hlm. 22-23) dalam bukunya yang berjudul Ragam Pengembangan Model Pembelajaran, yaitu: (1) Menyampaikan tujuan dan memotivasi peserta didik; (2) Guru menyajikan informasi kepada peserta didik untuk 
membentuk kelompok 3-5 orang; (3) Menyajikan informasi; (4) Guru memberikan tugas berupa Lembar Kerja Peserta Didik (LKPD) pada setiap kelompok; (5) Peserta didik yang mampu mengerjakan tugas pada Lembar Kerja Peserta Didik (LKPD) menjelaskan pada anggota kelompok lainnya sehingga semua anggota kelompok dapat mengerti dan memahami materi tersebut; (6) Guru memberi tes atau kuis individual kepada peserta didik. Pada saat tes atau kuis diharapkan peserta didik tidak saling membantu satu sama lain; (7) Guru memberikan penghargaan (reward) kepada kelompok yang memiliki nilai yang dikategorikan sangat baik; (8) Guru memberikan evaluasi dari materi yang sudah diajarkan.

\section{METODE PENELITIAN}

Jenis penelitian yang digunakan adalah Penelitian Studi Kepustakaan. Menurut Zed (2008, hlm. 1) mengungkapkan bahwa penelitian studi kepustakaan merupakan jenis penelitian yang memanfaatkan sumber pustaka untuk memperoleh data penelitian. Studi kepustakaan membatasi kegiatan hanya dari sumber data pustaka saja tanpa memerlukan penelitian dilapangan. Menurut Yaniawati (2020) "penelitian kepustakaan dilaksanakan dengan menggunakan literatur (kepustakaan) dari penelitian sebelumnya".Metode penelitian kualitatif dalam penelitian ini yaitu menggunakan metode dokumentasi. Yaniawati (2020) mengemukakan bahwa pengkajian atau pengintrepretasian bahan tertulis berdasarkan konteksnya merupakan metode dokumentasi. Bahan tersebut bisa berupa catatan yang terpublikasikan, buku teks, surat kabar, majalah, surat-surat, film, catatan harian, naskah, artikel \& sejenisnya. Jika semua data sudah terkumpul, maka akan dilakukan analisis data. Analisis data yang digunakan yaitu: a) Deduktif, Menurut Yaniawati (2020), mengungkapkan "Deduktif adalah pemikiran yang bertolak pada fakta-fakta yang umum kemudian ditarik pada suatu kesimpulan yang bersifat khusus.”; b) Induktif, Menurut Yaniawati (2020), megungapkan "Induktif adalah mengambil suatu konklusi atau kesimpulan dari situasi yang kongkrit menuju pada hal-hal yang abstrak, atau dari pengertian yang khusus menuju pengertian yang bersifat umum.”; c) Histori, Menurut Yaniawati (2020), mengungkapkan "Historis adalah melakukan analisis kejadian-kejadian dimasa yang lalu untuk mengetahui kenapa dan bagaimana suatu peristiwa itu telah terjadi.

\section{HASIL DAN PEMBAHASAN}

Berdasarkan pemaparan hasil penellitian-penelitian sebelumnya, dapat diperoleh informasi yang diperoleh bahwa dapat dikatakan kemampuan pemahaman matematis peserta didik yang masih kurang. Oleh karena itu, diperlukannya pengembangan kemampuan 
pemahaman matematis peserta didik. Terlihat bahwa peserta didik hanya menghafal dari sebuah rumus tetapi tidak memahami makna nya juga belum dapat menerapkan konsep pada masalah yang sederhana ataupun khusus.

Secara keseluruhan model pembelajaran Student Teams Achievement Division (STAD) adalah berdampak sangat positif pada pembelajaran. Namun demikian, masih ada kelemahan yang perlu diperbaiki diwaktu mendatang. Kelemahan pada model pembelajaran ini ialah karena peserta didik belum terbiasa menggunakan model pembelajaran Student Teams Achievement Division (STAD) untuk belajar dikelas, sehingga diperlukan waktu yang cukup untuk membiasakan model pembelajaran tersebut dengan peserta didik. Untuk mencapai tujuan pembelajaran, seseorang harus memahami kelebihan dan kekurangan model pembelajaran yang diterapkan.

Penggunaan model pembelajaran Student Teams Achievement Division (STAD) memberikan pengaruh kemampuan pemahaman matematis pada peserta didik. Hasil penelitian pada tingkat Sekolah Menengah Pertama (SMP) dan tingkat Sekolah Menengah Atas (SMA), menghasilkan dampak yang positif terhadap kemampuan pemahaman matematis. Selain itu, model pembelajaran Student Teams Achievement Division (STAD) memicu peserta didik dapat memahami serta dapat menyelesaikan permasalahannya.

Hal ini sejalan dengan pendapat Fakhrudin, et al,.(2014, hlm. 120) faktor dalam keberhasilan dalam model pembelajaran Student Teams Achievement Division (STAD) pada awal pembelajaran mendapatkan pengetahuan awal melalui penyajian materi yang diberikan oleh guru, pada penyajian materi memberikan arahan dan menyajikan sebuah contoh kepada peserta didik sebagaimana memulai proses menggali suatu masalah agar dapat menyelesaikan suatu masalah, yang diawali dengan menyajikan masalah khusus dari permasalahan sebenarnya, dalam masalah khusus yang diajukan tersebut peserta didik dibimbing untuk mendapatkan ide sehingga mendapatkan solusi dari permasalahan yang sebenarnya dan benar.

Setelah memperoleh pengetahuan awal kemudian peserta didik diberikan permasalahan yang harus diselasaikan bersama dengan teman sekelompoknya, hal ini mendorong peserta didik untuk belajar secara mandiri dan menumbuhkan sikap saling kerjasama antar peserta didik selama diskusi kelompok. Dikahir dalam pembelajaran dapat dilakukan dengan menarik kesimpulan secara bersama-sama sehingga peserta didik dapat lebih mudah mengingat dan memahami materi yang sudah diajarkan. Ada beberapa hal yang menjadi faktor dalam meningkatkan motivasi peserta didik ialah adanya penghargaan yang 
diberikan kepada kelompok terbaik berdasarkan skor kuis masing-masing kelompok. Hal ini tentu menjadi motivasi untuk para peserta didik. Disamping fakta tersebut, banyak sekali penelitian yang mengatakan bahwa model pembelajaran student teams achievement division (STAD) memberikan pengaruh positif juga secara signifikan memberikan peningkatan yang baik pada tingkatan SMP dan SMA.

\section{KESIMPULAN}

Berdasarkan hasil analisis yang dilakukan maka diperoleh kesimpulan sebagai berikut;

(1) Analisis hasil penelitian menjelaskan bahwa, kemampuan pemahaman matematis adalah kemampuan individu untuk memahami, menjelaskan, serta mengungkapkannya kembali suatu materi pelajaran, dalam pelajaran matematika individu dapat menggunakan konsep, dapat menerjemahkan ke dalam bentuk lain misalnya dari kata-kata menjadi simbol, tabel, grafik, atau bentuk lainnya serta dapat menginterpretasikan ke bentuk penjelasan ringkasan, dan mengaplikasikannya pada kasus yang sederhana atau khusus; (2) Analisis hasil penelitian menjelaskan bahwa, model pembelajaran yang menuntut peserta didik secara aktif salah satunya model pembelajaran Student Teams Achievement Division (STAD). Model pembelajaran ini dikembangkan oleh Robert Slavin, pembelajaran ini terdiri dari lima langkah yaitu; penyajian materi, pembagian kelompok,tes individual,perhitungan skor individu, dan rekognisi kelompok;

(3) Kemampuan pemahaman matematis pada tingkatan Sekolah Menengah Pertama (SMP) dan Sekolah Menengah Atas (SMA) dengan menggunakan model pembelajaran Student Teams Achievement Divison (STAD) memberikan dampak yang positif terhadap hasil belajar peserta didik hal ini terbukti dengan terjadinya peningkatan kemampuan pemahaman matematis.

\section{REKOMENDASI}

Berdasarkan hasil penelitian dapat diketahui kemampuan pemahaman matematis merupakan kemampuan yang paling dasar yang dimiliki siswa, dan penggunaan model pembelajaran Student Teams Achievement Divison (STAD) berdampak positif pada hasil belajar peserta didik. Karena itu peneliti memberikan saran kepada sekolah dan guru untuk melakukan penelurusan terkait dengan karya ilmiah yang relevan, juga jika pembaca tertarik dalam melakukan penelitian sejenis pada kemampuan kognitif lainnya. Karena tidak 
menutup kemungkinan dengan model pembelajaran ini berpengaruh terhadap aspek kognitif lainnya.

\section{UCAPAN TERIMAKASIH atau CATATAN}

Bagian ucapan terimakasih berisi ucapan terima kasih kepada pihak-pihak (jika ada) yang telah membantu dalam kegiatan penelitian yang dilakukan. Pihak-pihak tersebut, misalnya penyandang dana penelitian, pakar yang berkontribusi dalam diskusi atau pengolah data yang terkait langsung dengan penelitian/penulisan.

\section{REFERENSI}

Amirullah, Busnawir, \& Fahinu. (2017). Pengaruh Penerapan Model Pembelajaran Kooperatif Tipe STAD Terhadap Kemampuan Pemahaman dan Penalaran Matematis Siswa SMA ( the Effect of the Implementation of Cooperative Learning Model STAD Type on. Jurnal Pembelajaran Berpikir Matematika, 2(2), 11-20.

Esminarto, Sukowati, Suryowati, N., \& Anam, K. (2016). Implementasi Model STAD Dalam Meningkatkan Hasil Belajar Siswa. BRILIANT: Jurnal Riset dan Konseptual, 1(1), 16-23.

Fadillah, S., \& Setiawan, M. H. (2013). Kemampuan pemahaman matematik siswa smp melalui penerapan pembelajaran kooperatif tipe stad. Jurnal Pendidikan Informatika Dan Sains, 2(2), 167-175.

Firmansyah, E. (2016). Peningkatan kemampuan pemahaman matematika melalui metode pembelajaran kooperatif tipe stad (student teams achievement divisions). Jurnal Ilmu Pendidikan (JIP) STKIP Kusuma Negara, 7(2), 41-58.

Kurniasih, Imas \& Sani, Berlin .(2015). Ragam Pengembangan Model Pembelajaran untuk Peningkatan Profesionalitas Guru. Surabaya: Kata Pena.

Marbun, F. M. (2019). Pengaruh model pembelajaran kooperatif tipe student teams achievement division (stad) terhadap kemampuan pemahaman konsep matematis. Cartesius : Jurnal Pendidikan Matematika, 2(1), 45-59.

Murnaka, N, P., \& Manalu, R. I. (2018). Penerapan Model Pembelajaran Student Team Achievement Division untuk Meningkatkan Kemampuan Pemahaman Konsep Siswa. UNION: Jurnal Pendidikan Matematika, 6(3), 317-328.

NCTM. (2000). Principles and Standards for School Mathematics. Reston VA: NCTM

Ntjalama, K. M., \& Murdiyanto, T. (2020). Pengaruh model pembelajaran kooperatif tipe stad berbantuan media kahoot! Terhadap kemampuan pemahaman konsep matematis siswa. Jurnal Riset Pendidikan Matematika Jakarta, 2(2), 13-20.

Nurhayati, D, M., \& Hartono. (2017). Implementation of cooperative learning model type STAD with RME approach to understanding of mathematical concept student state junior high school in Pekanbaru Implementation of Cooperative Learning Model Type STAD with RME Approach to Understanding of Ma. AIP Conference Proceedings, 040003, 1-6. https://doi.org/10.1063/1.4983940

Partana, C. F. (2008). Kajian efektivitas penerapan metode pembelajaran kooperatif tipejigsawdan stad·pada mata pelajaran ipa aspek kimia di smp2 mlatisleman. Jurnal Cakrawala Pendidikan, 2(2), 152-163.

Rahayu, E. Y., Purwanto, S., \& Meiliasari. (2020). Pengaruh Model Pembelajaran Kooperatif Tipe Student Team Achievement Divisions ( STAD ) Berbasis Mind Mapping terhadap Kemampuan Pemahaman Konsep Matematis Peserta Didik di 
SMP Negeri 232 Jakarta. Jurnal Riset Pendidikan Matematika Jakarta, 2(2), 5058.

Ridia, Noni, S., \& Afriansyah, Ekasatya, A. (2019). Perbandingan Kemampuan Pemahaman Matematis Siswa melalui Auditory Intellectualy Repetition dan Student Teams Achievement Division Mosharafa : Jurnal Pendidikan Matematika Mosharafa : Jurnal Pendidikan Matematika. Mosharafa: Jurnal Pendidikan Matematika, 8(3), 515-526.

Saragih, S., \& Rahmiyana. (2013). Peningkatan kemampuan komunikasi matematis siswa sma / ma di kecamatan simpang ulim melalui model pembelajaran kooperatif tipe stad the increase of senior high school ( sma / ma ) students' mathematical communication skills in simpang ulim through stad. Jurnal Pendidikan Dan Kebudayaan, 19(2), 174-188.

Septian, A., Agustina, D., \& Maghfirah, D. (2020). Model Pembelajaran Kooperatif Tipe Student Teams Achievement Division ( STAD ) untuk Meningkatkan Pemahaman Konsep Matematika. Mathema Journal, 2(2), 10-22.

Siregar, T. J. (2019). Pengaruh pembelajaran kooperatif tipe stad terhadap peningkatan kemampuan pemecahan masalah matematis siswa smp. Jurnal Pendidikan Matematika (AXIOM), VIII(1), 15-25.

Sriyanti, I., \& Yaniawati, R. P. (2017). Peningkatan kemampuan pemahaman matematika siswa smp pgri pamanukan melalui model pembelajaran. Pasundan Journal of Research in Mathematics Learning and Education, 2(2), 108-115.

Suherman, E. (2012). Belajar dan Pembelajaran Matematika. Bandung: Universitas Pendidikan Indonesia.

Suriani, T., \& Rahamawati, Y. (2019). Pengaruh model pembelajaran kooperatif tipe stad melalui teknik hands on mathematics berbantuan lks terhadap kemampuan pemahaman konsep dan pemecahan masalah matematis di kelas viii smpn 43 padang. Journal of RESIDU, 3(22), 90-96.

Syarifah, L. L. (2017). Analisis kemampuan pemahaman matematis pada mata kuliah pembelajaran matematika sma ii. Jurnal Pendidikan Dan Pemberdayaan Masyarakat ( JPPM), 10(2), 57-71.

Tarim, K., \& Akdeniz, F. (2008). The effects of cooperative learning on Turkish elementary students ' mathematics achievement and attitude towards mathematics using TAI and STAD methods. Educational Studies in Mathematics, 67(1), 77-91. https://doi.org/10.1007/s10649-007-9088-y

Wahyuni, P. (2019). The Effect of Cooperative Learning Type Student Teams Achievement Division ( STAD ) on Understanding Mathematical Concepts in Class VIII Students of MTs N Pekanbaru. International Journal of Trends in Mathematics Education Research, 2(4), 168-172.

Yaniawati, P. (2020). Penelitian Studi Kepustakaan (Library Research). Bandung Yanuar, Sukamawati, Klara, I., \& Arifin, S. (2019). Penerapan Model Student Teams Achievement Division Terhadap Kemampuan Pemahaman Konsep Matematika Siswa Kelas VIII. UNION: Jurnal Pendidikan Matematika, 7(1), 57-64.

Yustinaningrum, B., Daulay, L. A., \& Putri, D. Y. (2019). Perbandingan model pembelajaran kooperatif tipe course review horraydan stad terhadap peningkatan pemahaman matematis siswa. MATH DIDACTIC: JURNAL PENDIDIKAN MATEMATIKA, 5(1), 43-51. 